\title{
Peruvian foreign policy in the new millennium: Continuity and change
}

\section{La política exterior peruana en el nuevo milenio: Continuidad y cambio}

\author{
Ronald Bruce St John ${ }^{1}$
}

\begin{abstract}
Following almost three decades of political instability, economic uncertainty, and activist diplomacy, President Alberto Fujimori in the early 1990 s returned a degree of economic and political stability to Peru. To restore the international standing of Peru, he also reoriented Peruvian foreign po-
\end{abstract}

1 Ronald Bruce St John earned an MA and $\mathrm{PhD}$ at the Josef Korbel School of International Studies, University of Denver. An affiliate professor at the Institute of International Studies, Bradley University, for 24 years, he also has been a guest lecturer at the Diplomatic Academy of Peru on several occasions. He has published 23 books and monographs and contributed to 28 others, including Toledo's Peru: Vision and Reality (2010), "Ideology and Pragmatism in the Foreign Policy of Peru" in Latin American Foreign Policies (2011), "Peru: a model for Latin American diplomacy and statecraft" in Routledge Handbook of Diplomacy and Statecraft (2012), and "The Peruvian Response to the Rise of Brazil" in Foreign Policy Responses to the Rise of Braqil (2016).

Contact: rbstjohn@comcast.net 
licy, modifying its direction, content, and tone. In the new millennium, successive Peruvian governments, from Alejandro Toledo to Ollanta Humala, have built on the initiatives introduced by Fujimori with a focus on traditional concerns, including sovereignty, territorial integrity, economic independence, regionalism, and continental solidarity. Notable for both continuity and coherence, Peruvian foreign policy after 2000 also evidenced a degree of pragmatism when an increasingly complex world called for new solutions to old problems.

Key words: Foreign policy, Alberto Fujimori, Alan García, Ollanta Humala, Alejandro Toledo

\section{Resumen}

Después de casi tres décadas de inestabilidad política, incertidumbre económica y diplomacia activista, el presidente Alberto Fujimori a principios de los años noventa devolvió al Perú la estabilidad económica y política. Para restaurar la posición internacional del país, también reorientó la política exterior, modificando su dirección, contenido y tono. En el nuevo milenio, los sucesivos gobiernos peruanos, desde Alejandro Toledo hasta Ollanta Humala, se han basado en las iniciativas introducidas por Fujimori, centradas en las preocupaciones tradicionales, como la soberanía, la integridad territorial, la independencia económica, el regionalismo y la solidaridad continental. La continuidad y la coherencia de la política exterior peruana después del año 2000 también evidenciaron un grado de pragmatismo en un mundo cada vez más complejo que pedía nuevas soluciones a viejos problemas. 
Palabras clave: Política externa, Alberto Fujimori, Alan García, Ollanta Humala, Alejandro Toledo

$$
* * *
$$

During the first term of President Fernando Belaúnde Terry (1963-1968), Peruvian foreign policy began to move in new directions, addressing unfamiliar issues, adopting fresh approaches, and consummating new bilateral and multilateral relationships. Successive Peruvian governments diversified arms transfers, broadened trade links, advocated a radical reorientation of the inter-American system, and pushed for enhanced regional economic cooperation. In a sustained period of innovation, each administration naturally emphasized different challenges and opportunities; however, the central direction of Peruvian foreign policy after 1963 reflected a continuity that transcended individual interests and goals. In pursuit of heightened Peruvian sovereignty, successive governments from Belaúnde to Fujimori sought to reduce external pressures and imposed conditions, especially from the United States. In the process, the intractable economic problems experienced by the Peruvian government repeatedly undermined key facets of Peruvian foreign policy. By the end of the first term of Alan García Pérez (1985-1990), Peru had defaulted on some $\$ 2$ billion in loans from the International Monetary Fund and other lending agencies, making it one of the leading debtor nations in the world (St John 1999b: 187-213). 


\section{Setting the stage, 1990-2000}

Alberto Fujimori, a virtual unknown in Peruvian political circles, won the 1990 presidential election by a commanding majority. After his election, Peruvian pundits referred to Fujimori's campaign as a tsunami, a powerful image reflecting the magnitude and velocity of his final electoral surge. Understandably, the deplorable state of the Peruvian economy was the first priority of the Fujimori government. In an effort to improve relations with the international financial community, President-elect Fujimori traveled to Japan and the United States before his inauguration, and less than two weeks after he took office, he announced the initial phase of a stern economic stabilization program. Dubbed Fujishock, it was based largely on orthodox economic policies he had denounced during the campaign (Boloña 1996; Iguíñez 1998).

Where the activist diplomacy of the García administration left little room for an improvement in bilateral relations with the United States, President Fujimori recognized that US government support was essential to the success of any attempt to restore the international standing of Peru. Consequently, he focused initially on the issues of drug production and drug trafficking, the policy areas of greatest interest to Washington. With Peruvians more concerned with combating guerrilla-terrorist movements, Fujimori's approach highlighted the early pragmatism of his government (Luna 1999). Expected to agree to a substantial infusion of US military assistance to combat the drug problem, the Fujimori administration later surprised most observers when it argued that the drug problem could not be solved by military means alone, proposing an alternative approach which went beyond simple security concerns to address economic 
issues. The Peruvian approach, which became the basis for a formal umbrella agreement concluded between Peru and the United States in 1991, responded more fully to Peruvian concerns and priorities than the US one and thus represented an early diplomatic victory for the Fujimori government. In May 1995, Peru and the United States concluded a new agreement to promote alternative development and economic growth in the coca-growing zones, and one year later, they renewed their joint commitment to fight drug trafficking (McClintock and Vallas 2003: 117-118, 122-124, 128129; St John 1999b: 206, 213).

In April 1992, President Fujimori executed an autogolpe, suspending the 1979 constitution, padlocking the congress, and dismantling the judiciary. Five months later, the Dirección Nacional contra el Terrorismo captured Abimael Guzmán, the founder of Sendero Luminoso, crippling a guerrillaterrorist movement that had challenged the existence of the state for more than a decade. As these events unfolded, more and more Peruvians approved of Fujimori's policies, especially his stabilization of the economy and his success in defeating guerrilla-terrorists; however, his mounting popularity did not silence criticism of alleged human rights abuses. The George H. W. Bush administration (1989-1993) condemned the autogolpe but refused to support broad economic sanctions on the grounds such action would jeopardize the war against terrorism in Peru (Ramacciotti and Méndez 2012: 105-106, 108-110; Palmer 1998: 26-27). In a 10 July 1992 cable to Secretary of State James A. Baker, the US Ambassador to Peru, Anthony C. E. Quainton, concluded just three months after the autogolpe that "Peru is heading in a direction which is consistent with our long-term interests" (Quiroz 2008: quote 372). 
As economic and political stability increased, the Fujimori government reinserted Peru into the international financial community and began to address issues of debt and development. This process was facilitated by the success of the economic reforms put in place after 1990. As stabilization policies ended a period of hyperinflation, economic growth increased, an ambitious privatization program picked up steam, exports increased, and the rate of foreign investment responded favorably to privatization and new investment laws. Efforts towards economic normalization culminated in a Paris Club agreement in July 1996 in which Peru restructured most of the US\$9.25 billion owed to official creditors (Iguíñez 1998).

The formal movement toward enhanced regional cooperation began during the first Belaúnde administration with the 1966 Declaration of Bogotá committing Chile, Colombia, Ecuador, Peru, and Venezuela to the negotiation of an economic integration agreement. The 1969 Cartagena Agreement, signed by Bolivia, Chile, Colombia, Ecuador, Peru, and later Venezuela, established the Andean Common Market or Andean Group (Ffrench-Davis 1978: 34-8). The administration of Juan Velasco Alvarado (1968-1975) enthusiastically supported the Cartagena Agreement, but the support of subsequent Peruvian governments wavered. The se70 cond Belaúnde administration (1980-1985) reaffirmed Peru's commitment to regional cooperation, but its approach to national development goals slowed progress toward Andean integration (Avery 1983: 156-65). In turn, the first García administration remained committed to the ideal of Latin American unity but demonstrated little interest in pursuing the strong initiatives necessary to resolve the growing crises faced by the Andean Group (St John 1999b: 201, 204). 
In contrast, President Fujimori sought from the start to accelerate the pace of regional integration. He presided over the opening meeting of the Andean Parliament when it convened in Lima in February 1991, and in May 1991, he joined the other Andean presidents for a two-day summit in Caracas. During the meeting, the participants agreed to establish a free trade zone by January 1992 and a common market by 1995. They also called for talks with the US government to discuss trade, investment, environmental, and drug trafficking issues, and they urged the US Congress to pass a bill under discussion which would encourage Andean agricultural workers to replace coca production with farm products exportable to the United States under preferential terms (St John 1996: 131-132). In early December 1991, the Andean presidents, under pressure from the Fujimori government to move forward with Andean integration, agreed in the Barahona Act to establish a free trade zone and a customs union in 1992. Unfortunately, the fallout from the autogolpe dealt a severe blow to ongoing efforts at regional cooperation and development (Seoane Flores 2000: 295-296). In August 1992, Peru announced its withdrawal from active participation in the Andean Group for a two-year period, and a few weeks later, Peru opposed a common external tariff during a meeting in Quito (St John 1999b: 218-220).

In January 1992, Peru concluded a 50-year renewable agreement with Bolivia in which Peru agreed to provide Bolivia with a duty-free port and an industrial park at the Peruvian port of Ilo in return for similar facilities at Puerto Suárez on the Paraguay River. Peru also ceded to Bolivia a tourist zone for 99 years, together with five kilometers of Ilo coastline. Bolivians immediately baptized the coastal strip "Boliviamar" (Ergueta Ávila 2000: 93-104). Both Bolivia and Peru 
hailed the pact as an historic step which would greatly benefit regional economic development (St John 1994: 24).

In 1992, the Fujimori government also embarked upon a new round of talks with Chile aimed at the full implementation of the terms of the 1929 Tacna and Arica Treaty and Additional Protocol (Tudela 1999). Following lengthy negotiations, the foreign ministers of Peru and Chile signed a package of documents on 13 November 1999 that collectively executed the 1929 agreements, ending 70 years of controversy (Novak 2000). Foreign Minister Fernando de Trazegnies, an author and dedicated bibliophile, later expressed his satisfaction that the settlement included the return to Peru of some 200 books and documents that Chilean forces had looted during the War of the Pacific (Trazegnies 1999). In mid-1998, Peru also reached a free trade agreement with Chile that immediately removed tariffs on some 2,500 products with duties on other products to be phased out over a three to 18 year period (St John 1999b: 221).

As the 1990s progressed, the Fujimori government was increasingly active in the Asia-Pacific region. As early as 1872, the Manuel Pardo administration (1872-1876) had dispatched a diplomatic mission to China and Japan, and while these early efforts to expand commercial and other ties met with limited success, President Fujimori later built on his Japanese heritage to promote investment and trade with the region, including China, South Korea, and Japan (Gardiner 1975: 1-21, 42-60, 94-110, 127-55; Morimoto 1999: 213-25). In 1991, Peru became a member of the Pacific Economic Cooperation Council (PECC) and the Pacific Basin Economic Council (PBEC), and in 1998, it joined the Asia-Pacific Economic Cooperation (APEC) forum (González Vigil 
2012: 209-210). When the Movimiento Revolucionario Túpac Amaru (MRTA) guerrilla-terrorist movement attacked the Japanese ambassador's residence in mid-December 1996, seizing 72 high-profile hostages, Fujimori authorized a successful commando raid in which all the guerrillas were killed. Widely popular in Japan, President Fujimori made his tenth visit to Japan in 1999 to mark the $100^{\text {th }}$ anniversary of the first wave of Japanese emigration to Peru (McClintock and Vallas 2003: 38, 74-75).

In January 1995, the armed forces of Ecuador and Peru clashed in the most serious round of fighting since 1941. After a sustained diplomatic effort, the four guarantors of the 1942 Rio Protocol (Argentina, Brazil, Chile, and the United States) in October 1998 announced a Global and Definitive Peace Agreement, generally known as the Brasilia Accords (Tudela 1999). The agreement delimited the boundary line in the unmarked sector on the summit of the Cordillera del Cóndor and provided for the creation of two national parks in the frontier zone under the sovereignty and jurisdiction of the respective states. Ecuador also received one square kilometer of ground in Peru on the point designated as Tiwinza, the site of heavy fighting in 1995, but this transfer of land did not entail any "consequences as to sovereignty" with Ecuador enjoying real title except the right to transfer the property (St John 1999a: 30-49; Bákula 2002: II, 1344-1367).

President Fujimori promised a period of socioeconomic and political reform; instead, he presided over a decade of authoritarian rule, marked by a level of corruption previously unknown in Peru. Despite widespread improbity and venality that trampled on human rights, compromised domestic policies, and undermined state institutions, the Fuji- 
mori administration enjoyed more success in advancing core objectives of Peruvian foreign policy than any other government in the second half of the twentieth century. President Fujimori restructured the foreign debt on highly favorable terms and restored Peru's standing in the international financial community, setting the stage for the pursuit of a more autonomous national development policy. Diplomatic and economic relations with important Asia-Pacific states expanded, and by the end of the decade, bilateral relations with the United States were the most positive in recent memory. The final implementation of the Tacna and Arica Treaty and Additional Protocol completed a process begun in 1929 when President Augusto B. Leguía (1908-1912, 1919-1930) negotiated the agreements, and the successful resolution of the Ecuador-Peru border dispute on terms highly favorable to Peru achieved a goal of successive Peruvian governments since independence.

\section{Interim Paniagua administration, 2000-2001}

Vladimiro Montesinos Torres, the de facto head of the Servicio de Inteligencia Nacional, advised President Fujimori on virtually every aspect of national policy, and he was at the center of the systematic evisceration of democratic institutions in Peru. Once the illicit activities of Montesinos became public knowledge, pro-Fujimori politicians lost control of congress, and President Fujimori fled to Japan where he faxed a letter of resignation to congress on 20 November 2000 (Rospigliosi 2000). After both the first and second vice presidents resigned, constitutional succession passed to the president of the congress, Valentín Paniagua, a widely respected politician, and on 22 November 2000, he was sworn 
in as the president of Peru for an interim, eight-month transitional period until a new president could be elected (Paniagua 2001). President Paniagua asked the esteemed diplomat and former UN secretary-general, Javier Pérez de Cuéllar, to form an interim cabinet. In addition to serving as prime minister, Ambassador Pérez de Cuéllar also assumed the portfolio of foreign minister (Pérez de Cuéllar 2012: 145-147).

Prime Minister Pérez de Cuéllar viewed the reinsertion of Peru into the international community as the most important foreign policy objective of the interim government. In support of this goal, the Peruvian delegation to the Third Summit of the Americas in Quebec in April 2001 proposed La Carta Democrática Interamericana (CDI), a document grounded in the OAS Charter. Ambassador Manuel Rodríguez Cuadros, Peruvian ambassador to the OAS at the time, was the architect of the CDI which was later adopted by the OAS General Assembly (Rodríguez Cuadros 2008; Negro 2012: 282-3). The interim government also moved to normalize relations with international bodies, like the International Criminal Court (ICC) and La Corte Interamericana de Derechos Humanos (CIDH), and it worked closely with the Comunidad Andina de Naciones (CAN) (García-Sayán 2008). Prime Minister Pérez de Cuéllar also made official visits to several neighboring states, including Argentina, Chile, Colombia, and Ecuador, and he moved to reform personnel practices within the Ministry of Foreign Affairs related to the mistreatment of professional diplomats in the Fujimori era (Pérez de Cuéllar 2012: 148-149). 


\section{Connecting with the outside world, 2001-2006}

Most of the candidates in the 2001 presidential race were centrist, pro-market, and emphatic about their democratic credentials. Stressing his indigenous roots and rise from poverty, Alejandro Celestino Toledo Manrique stood between his two main competitors, former President Alan García Pérez, a center-left populist, and Lourdes Flores Nano, a center-right conservative (St John 2010: 27-31). Toledo handily defeated García in the second round with 53 per cent of the vote, and before all the ballots had been counted, he affirmed his democratic credentials, promising to be a "president for all Peruvians" (quoted in El Comercio, 4 June 2001).

Building on the foreign policy of the Fujimori government, the Toledo administration pursued nine interrelated foreign policy goals. First, it continued the familiar Peruvian emphasis on expanded integration with regional and international organizations. Second, it targeted stronger relations with the major industrialized states and the Asia-Pacific region. Third, it promoted democracy and human rights, often tying a fourth policy goal, the struggle against poverty, to the promotion of democracy. Fifth, it advocated a reduction in regional arms spending, arguing the money would be better spent on education, health, and poverty reduction. Sixth, it worked to broaden relations with neighboring states, emphasizing development in the borderlands. Seventh and eighth, it called for the Ministry of Foreign Affairs to be more effective in promoting the domestic economy abroad and to do a better job of serving the more than 2 million Peruvians living overseas. Finally, the Toledo government continued ongoing reforms at the Ministry of Foreign Affairs (Toledo 2008; García-Sayán 2002: 18-27). 
Continuing a policy of active participation in multilateral economic groupings with a long tradition in Peru, President Toledo emphasized the need for Peru to expand its relations with numerous regional and international bodies, promising in his July 2001 inaugural address a foreign policy that would connect Peru with the outside world. He called for CAN to be relaunched to accelerate regional integration, and he also urged it to adopt a multilateral approach to arms control, directing the resultant savings to social welfare programs (Toledo 2001). The García administration also had promoted arms control, but it based its approach on the need to reduce regional tensions and to manage the external debt crisis as opposed to the more compelling social rationale developed by President Toledo (St John 1999b: 203-204). In late 2002, CAN concluded a free trade agreement with the Mercado Común del Sur (MERCOSUR), and in March 2003, it agreed to work with the Área de Libre Comercio de las Américas (ALCA) and the European Union to pursue a joint strategy against poverty, drugs, and terrorism (Ministerio de Relaciones Exteriores 2006a: 42).

The Toledo government assumed a wider leadership role in CAN after Ambassador Allan Wagner, a long-time proponent of regional integration, was elected secretary-general of the organization in November 2003. Wagner argued that a higher level of integration would provide optimum solutions to regional issues like the Peru-Chile maritime dispute and Bolivia's demand for a sovereign Pacific port (Expreso, 1 July 2004). During Peru's tenure as president pro tempore of CAN (20042005), one of the group's most noteworthy achievements, in terms of the foreign policy of the Toledo administration, was UN General Assembly approval in September 2004 of the creation of a Zona de Paz Andina, an Andean zone free of 
biological, chemical, and nuclear weapons. Internal disputes, aggravated by disparate socioeconomic and political visions, later disrupted CAN activities. In mid-April 2006, Venezuelan President Hugo Chávez, a vocal critic of the market reform and free trade policies advocated in the Miami Consensus, withdrew Venezuela from CAN after Colombia and Peru concluded free trade agreements with the United States. Chávez then joined Fidel Castro and Bolivian President Evo Morales in forming what became the Alianza Bolivariana para los Pueblos de Nuestra América (ALBA), a socialist alternative to ALCA (Philip and Panizza 2011: 1-12, 149-173).

In a policy distinct from its predecessors, the Toledo administration also promoted for major reforms to key multilateral political groupings. In the spring of 2003, Foreign Minister Allan Wagner spearheaded an initiative within the Grupo de Río (G-Río) to reform the UN collective security system, calling for an increase in membership on the Security Council, elimination of the veto power of the five permanent members, and revision of the collective security system to better manage threats to international peace (Wagner 2003). The Cusco Consensus, a joint statement issued in May 2003 at the end of the seventeenth G-Río summit, identified the strengthening of democratic governance as the main G-Río mission, tied its strengthening to poverty alleviation, and ca-

78 lled for UN reforms similar to those identified earlier by Foreign Minister Wagner (St John 2003). The Comunidad Sudamericana de Naciones (CSN), created in December 2004 and renamed the Unión de Naciones Suramericanas (UNASUR) in April 2007, later targeted a gradual convergence of CAN and MERCOSUR through political dialogue, physical integration, and social cohesion (Ministerio de Relaciones Exteriores 2006c, 235-240). 
The Toledo administration also championed familiar issues like reduced arms spending, democracy, and human rights in other forums, including the Organization of American States and the United Nations (St John 2010: 173). In mid-September 2001, only two months after Toledo's inauguration, the OAS General Assembly adopted the CDI in the course of an extraordinary session in Lima, and central aspects of the CDI later found their way into the 2003 Cusco Consensus. In April 2002, the UN Human Rights Commission adopted a Peruvian resolution that defined the core elements of democracy as respect for human rights, freedom of association, and free elections based on universal suffrage. In October 2005, Peru was elected a nonpermanent member of the UN Security Council for 2006-2007; in January 2006, Peru assumed the presidency of the UN Human Rights Commission; and in May 2006, it was elected to the newlycreated UN Council on Human Rights (St John 2010: 173).

Elsewhere, the Organización de Estados Iberoamericanos (OEI) in November 2001 issued La Declaración de Lima, a lengthy statement in support of democracy, human rights, and reduced arms expenditures that mirrored the domestic and foreign policy agenda of the Toledo administration (Rodríguez Cuadros 2008). In January 2004, an Extraordinary Summit of the Americas met in Monterrey, Mexico, and one of the few notable proposals adopted was a Peruvian initiative, La Declaración de Nuevo León, affirming that the well-being of the people of the Americas required social development, economic growth with equity, and democratic government. Otherwise, the Monterrey summit failed to find either a common language or common ground, and the lack of substance at the meeting was aptly summarized as "una cumbre con pocas nueces" (El Comercio, 16 January 2004). 
The two-day summit of Arab and Latin American leaders that met in May 2005 was another international gathering that offered little in the way of noteworthy, concrete results (Rodríguez Cuadros 2008).

In March 2002, President George W. Bush became the first sitting US president to visit Peru, arriving in Lima only days after a car bomb exploded outside the US embassy. During his visit, President Bush reiterated an earlier US pledge to triple aid to combat drug trafficking, announced the return of the Peace Corps to Peru after almost three decades, and reaffirmed his commitment to renew the Andean Trade Preferences Act (ATPA). He also expressed the hope that the case of Lori Berenson, a New York woman convicted in June 2001 of collaborating with the MRTA guerrilla-terrorist movement, could be referred to the CIDH. In September 2002, President Toledo visited the United States, finalizing a $\$ 300$ million US commitment to fund alternative crop development and garnering sizable new credits from the World Bank and Inter-American Development Bank (IADB) (Ramacciotti and Méndez 2012: 120-124; McClintock and Vallas 2003: 161).

Even as bilateral relations strengthened, President Toledo took foreign policy decisions that were unwelcome in Wash-

80 ington (Maúrtua de Romaña 2006). Peru refused to support the March 2003 US-led invasion of Iraq on the grounds it had not been approved by the UN Security Council. Trade tensions also increased over time with the Peruvian government arguing the Bush administration was holding progress in bilateral talks hostage to Peruvian resolution of outstanding disputes with US companies. Another source of tension was the Peruvian refusal, having ratified the Rome Sta- 
tute of the International Criminal Court, to accede to US demands that its citizens be shielded from ICC prosecution in a bilateral immunity agreement (St John 2010: 177-178). Finally, with little sympathy for Lori Berenson in Peru, President Toledo hailed a November 2004 CIDH decision that she must serve out her prison term (Berenson 2005).

Despite these policy differences, the Toledo government was able to maintain a strong working relationship with the Bush administration. In a May 2003 interview, for example, President Toledo described the chemistry of his personal relationship with President Bush as a level of closeness to skin itself (Toledo 2003). The United States embraced the Peruvian approach in areas like the promotion of democracy, human rights, and free trade at a time when populist, socialist regimes in Bolivia, Ecuador, and Venezuela increasingly offered alternatives unwelcome in Washington (McClintock and Vallas 2010: 197, 199). In the process, Presidents Bush and Toledo developed a strong personal relationship, albeit not one without its critics. "Some say Peru is the unconditional ally of the United States," Ambassador José de la Puente Radbill, a former foreign minister of Peru, wryly observed in the course of a May 2003 conversation; however, "it might be better to be an ally with conditions" (Puente Radbill 2003).

In December 2002, Peru concluded an agreement with the European Union in which the latter agreed to provide €86 million in financial aid to support improved governance, stronger institutions, socioeconomic development, and integration. At the same time, the Toledo government expanded bilateral relations with several European states, including Belgium, France, Germany, Great Britain, Italy, Russia, and 
Spain. Germany was especially generous, designating Peru a country for "concentrated cooperation," and Spain also provided substantial amounts of economic aid. In turn, France and Italy agreed to swap debt for socioeconomic development in Peru (Novak 2012: 183-185, 192-193, 198-203; Ministerio de Relaciones Exteriores 2006b: 30-31).

In an increasingly important shift in Peruvian foreign policy, President Toledo also continued the efforts of the Fujimori administration to expand commercial and diplomatic ties with the Asia-Pacific region. In December 2004, China declared Peru an official tourist destination, and in January 2005, China and Peru concluded several agreements related to agriculture, tourism, and energy exploitation. Six months later, President Toledo traveled to China where he met with President $\mathrm{Hu}$ Jintao and signed new agreements related to education, health, tourism, and transportation. In September 2005, Peru opened a consulate in Guangzhou, and in October 2005, China and Peru signed a memorandum of understanding covering cooperation in technological information and communications (Ministerio de Relaciones Exteriores 2006b: 32, 50). In an April 2006 interview, President Toledo stressed the importance of China to Peru, adding in a jocular manner that he was not overly ambitious in regards to China and would be satisfied with 5 percent of the China

82 market (Toledo 2006).

President Toledo hoped to build on the strong relationship with Japan developed by his predecessor, but the Japanese government's reluctance to extradite Fujimori soured bilateral relations (Maúrtua de Romaña 2006). After Fujimori flew to Chile and announced plans to return to Peru and run in the 2006 presidential election, Chilean authorities arrested him, 
but efforts to extradite the former president to Peru dragged on for months. Elsewhere in Asia, the Toledo administration in November 2005 concluded a free trade agreement with Thailand, and in February 2006, the two states signed an air transport agreement. In November 2005, South Korea and Peru exchanged ratifications for an extradition treaty, and in February 2006, Peru opened a resident embassy in Vietnam (Ministerio de Relaciones Exteriores 2006a: 85-86; Ministerio de Relaciones Exteriores 2006b: 32, 50).

Throughout the Toledo administration, Peru-Ecuador relations were dominated by mutual efforts to fulfill the terms of the Brasilia Accords with financial commitments and disbursements most often the topics of discussion. Unfortunately, international aid commitments failed to reach the target of $\$ 3$ billion over 10 years; aid disbursements never matched early aid commitments; and the expected growth in bilateral trade developed slower than anticipated (GarcíaSayán 2008). Over time, agreements on numerous issues, from drugs to sanitation to conservation, were concluded or implemented as bridges, roads, electrical networks, and other transportation or communication facilities were constructed or upgraded. Bilateral and multilateral investment in the borderlands also continued with Peru performing significantly better than Ecuador in this regard (Arróspide del Busto 2008).

With Bolivia, most of the issues faced by the Toledo administration carried over from the Fujimori era with the most important one being Ilo as an exit port for Bolivian energy. Following the inauguration of President Gonzalo Sánchez de Lozada, the Toledo administration in August 2002 proposed to route Bolivian natural gas through a pipeline pa- 
rallel to the La Paz-Desaguadero-Ilo road. After President Sánchez de Lozada rejected the Peruvian proposal because it did not include a sovereign outlet to the Pacific, Bolivian opposition movements in October 2003 forced him to flee the country, and he was replaced by Vice President Carlos Diego Mesa Gisbert (Sánchez de Lozada 2003). When Presidents Toledo and Mesa in August 2004 signed a letter of intent for Bolivian natural gas to be exported to Mexico and the United States through an unspecified Peruvian port, its terms led to widespread protests in Bolivia, leading to President Mesa's resignation in early June 2005 (St John 2005). Eduardo Rodríguez Veltzé, chief justice of the Supreme Court, was then sworn in as an interim president with the task of conducting general elections before the end of the year (García-Corrochano 2012: 82-83).

Following the December 2005 election of Evo Morales, Peru-Bolivia relations were on hold (St John 2006a). In addition to a leftward tilt in Bolivian politics, deep philosophical differences separated Presidents Toledo and Morales. Where Toledo promoted orthodox economic policies and free market reforms in Peru, Morales questioned the benefits of globalization, advocating nationalization and socialism in Bolivia. Where Toledo signed a free trade agreement with the United States, Morales signed a people's trade agreement

84 with Cuba and Venezuela. Where Toledo expanded ties with international trade and finance organizations, Morales looked to the alternative trade and finance structures promoted by President Chávez. Where Toledo cultivated bilateral ties with a wide variety of states, including the United States, Morales allied with a smaller number of mostly leftleaning states, like Cuba, Nicaragua, and Venezuela. Finally, President Toledo rejected the populist appeal of Morales, 
denouncing populism "as a one night party that inevitably will end up in a funeral" (Toledo 2006).

With a strategic relationship with Brazil under consideration at the Torre Tagle for many years, President Toledo and Brazilian President Luiz Inácio Lula da Silva laid the groundwork for an agreement in April 2003, concluding a wideranging strategic alliance with ambitious goals in August of that year (St John 2010: 148). First, the two heads of state agreed to promote increased cooperation and development within the framework of La Iniciativa para la Integración de la Infraestructura Regional Suramericana (IIRSA), a multinational initiative comprising 10 axes or hubs of economic integration, crisscrossing the South American continent. Second, they agreed to promote bilateral trade and investment within the context of the Acuerdo de Complementación Económica (ACE) between Peru and MERCOSUR. Third, they agreed to negotiate Peruvian access to two surveillance systems Brazil was developing in the Amazon Basin to provide meteorological data and real-time information on illegal activities, including drug trafficking and illicit deforestation. Other goals included support for democracy and the rule of law, the promotion of human rights as a key element of socioeconomic development, and the creation of improved conditions for friendship, understanding, commerce, and transit (St John 2016: 147-149; Novak and Namihas 2012: 123-155). Foreign Minister Wagner, a professional diplomat not given to hyperbole, later described the agreement as the most important event in Peruvian foreign policy in the last 30 years (Gestión, 26 August 2003).

During the Toledo administration, bilateral relations with Colombia centered on national security issues involving te- 
rrorism and the war on drugs. Peru and Colombia concluded several agreements aimed at combating terrorism, drug trafficking, and arms smuggling. To reduce military expenditures and to better prioritize social spending, they also worked to improve economic conditions in the borderland. As investment and trade increased, they concluded an innovative agreement designed to facilitate commercial and tourist traffic in the frontier zone. It called for both states to treat air travel in the borderland as domestic travel, simplifying customs and tariff procedures (Namihas 2012: 60, 63; Ministerio de Relaciones Exteriores 2006a; 77).

With President Toledo a vocal advocate of reduced military spending in the Americas, Chilean arms purchases were a persistent bilateral issue after 2001. An increasingly testy dispute over the Peru-Chile maritime boundary further complicated relations. Involving thousands of square kilometers of Pacific Ocean, national pride, rich fishing grounds, and other potentially important undersea resources were at stake in the dispute (Rodríguez Cuadros 2008). Frustrated with what it viewed as Chile's stalling tactics, the Toledo government eventually resolved to take the issue to the International Court of Justice (ICJ) at The Hague (St John 2010: 153155). On a more positive note, the Toledo administration did succeed in negotiating what it termed a social agenda with 86 Chile, addressing the common social security, health care, and other concerns of Peruvians living in Chile and Chileans working in Peru (García-Corrochano 2012: 80-81).

In the closing days of the Paniagua government, diplomatic relations with Venezuela reached a low over Peruvian charges that Venezuelan officials were shielding Vladimiro Montesinos Torres. When Montesinos was detained in June 2001, 
President Chávez accused Peru of violating Venezuelan sovereignty in carrying out the arrest, suggesting Peru was seeking to discredit his self-styled revolution (El Comercio, 18 July 2001). As the dispute worsened, President-elect Toledo fueled the fire, expressing his distaste for Chávez's brand of populism and warning of the dangers of what he termed Fujimorism with a different face. While conflict more than cooperation marked relations between Peru and Venezuela throughout the Toledo years, bilateral trade continued to grow with the balance in Venezuela's favor (St John 2010: 158-159).

In 2001-2006, social diplomacy, for the first time, became a stated foreign policy goal of Peru even though many elements of the concept were not new. Countries like Peru have long understood their governments must focus resources on helping citizens to combat poverty through increased participation in multilateral bodies concerned with socioeconomic development. Ambassador Manuel Rodríguez Cuadros, either vice minister or minister of foreign affairs for 50 of the 60 months Toledo was in office, was an especially strong proponent of social democracy, arguing diplomacy must serve the Peruvian people (Rodríguez Cuadros 2008). With almost 10 percent of the Peruvian population living abroad, the Toledo government also worked to improve services and protection for this substantial and growing expatriate population (Tapia Samaniego 2011: 22-25, 43-49, 84-86, 71 77). In addition, the Ministry of Foreign Affairs continued the personnel reforms initiated by the Paniagua administration. After congress set new standards for the diplomatic corps, including a "diplomatic clause" which stated that in the future no one in the ministry should be expected to obey an authoritarian government, 51 of the 117 diplomats arbi- 
trarily and unconstitutionally dismissed by the Fujimori administration in 1992 were reinstated. Of the remaining 66 diplomats, a few had been reinstated earlier and others had passed the mandatory retirement age or died (García-Sayán 2002: 220-234, 241-245).

In pursuit of its goal to better connect with the outside world, the Toledo administration was a highly visible, often effective player in regional and international organizations. Relations with the industrialized world, especially Europe and the United States, focused on increased aid, trade, and investment through the promotion of human rights and democracy, together with cooperation in the fight against drug trafficking and terrorism. At the same time, diplomatic and commercial relations with China and other Asian states reached new heights. Successful in many areas, the foreign policy initiatives of the Toledo government sometimes lacked substance and purpose. There was a tendency to advance broad themes, like democracy and human rights, but fail to bring them to practical application and implementation. There was also a tendency to pursue issues of debatable viability, like multilateral disarmament and reduced arms spending, admirable in their own right but almost certainly incapable of execution. Concerning regional integration, the Toledo government strengthened traditional ties and developed new ones, but it sometimes failed

88 to take the concrete economic steps necessary to advance the political side of the equation. These criticisms aside, the Toledo administration was generally successful in the pursuit of its regional and international objectives. In the process, the foreign policy of the Toledo administration connected Peruvians to the outside world to a far greater extent than any previous government, strengthening the credibility and global reputation of the state. 


\section{Blending old and new, 2006-2011}

Former President Alan García Pérez successfully reinvented himself in the course of the 2006 presidential campaign. Depicting himself as an elder statesman who had learned from his mistakes, he targeted his message at younger Peruvians with no memory of his disastrous first administration. After coming in second in the first round of elections, García overcame Ollanta Humala Tasso in the second round with 52 per cent of the vote (St John 2006b).

President García's inaugural address focused on domestic issues. In one of the few references to foreign policy, he pledged to maintain economic development and growth at a rate equal to or greater than that of his neighbors. He also promised to maintain an international focus but reduce travel abroad, reflecting widespread criticism that his predecessor had spent too much time outside Peru (Toledo 2006). In line with his emphasis on thrift in government, the Ministry of Foreign Affairs announced it would close six embassies, a symbolic rejection of Toledo's policy of promoting a wider, more visible international role for Peru. Ironically, President García was later criticized for not traveling abroad enough (Álvarez-Rodrich 2008).

Before his inauguration, García told a syndicated columnist in Miami that "Peru's foreign policy has not been the most misguided part of Toledo's government. So we must continue with [current policies] in issues such as opening up to the world market and drawing investments in a framework of democracy" (Miami Herald, 11 June 2006). Once in office, he pursued a foreign policy that was a blend of old and new but most often mirrored the policies of President Toledo. 
In an August 2006 interview, Foreign Minister José Antonio García Belaúnde was mildly critical of Toledo’s foreign policy, yet proceeded to outline a set of goals little changed from it (La República, 3 August 2006). Support for market-friendly policies replaced the emphasis on socialism in the first García administration, and after questioning the free trade agreement with the United States during the election campaign, García embraced it once in office. President García never developed the close personal relationship with President Bush enjoyed by Toledo; nevertheless, his multiple visits to the White House were a remarkable achievement for someone who was in effect persona non grata in Washington by the end of his first term (Ministerio de Relaciones Exteriores 2011: 74-75, 116, 219-220; Ramacciotti and Méndez 2012: 127-136).

The García administration continued the policies of Presidents Fujimori and Toledo in a variety of regional and international bodies; however, it did not pursue as aggressively as the Toledo government specific initiatives in areas like the promotion of democracy and the reduction of regional arms expenditures (Ministerio de Relaciones Exteriores 2011: 183-187, 233-235). When it came to social diplomacy and better serving Peruvians abroad, President García also embraced many of the initiatives of Toledo. Foreign Minis-

90 ter García Belaúnde later proudly noted that Peru in 2011 had 108 consuls or consular sections abroad plus 136 honorary consuls (Tapia Samaniego 2012: 25-32, 67-70). The García administration maintained good relations with Israel, but it also promoted wider relations with the Arab World. Peru sent its first ambassador to Qatar, recognized the Palestinian State as sovereign and independent, and opened trade talks with the six Arab Gulf states. It also hosted the third 
summit of América del Sur-Países Arabes (ASPA) in October 2012 (García 2012; Ministerio de Relaciones Exteriores 2011: 176-178, 229, 279).

President Toledo had worked hard to increase trade and investment with China, and the García administration augmented the initiatives in place, building on existing agreements in areas like education, health, and transportation. Peruvian exports to China grew, and visits between Chinese and Peruvian leaders became a frequent occurrence, including visits by President García to China in 2008 and 2010. Ongoing participation in APEC forums helped Peru to conclude free trade agreements with Singapore in 2008 and China in 2010. The García administration also concluded a free trade agreement with the European Free Trade Association in 2010 and a free trade agreement with South Korea and a commercial agreement with Japan in 2011 (Ministerio de Relaciones Exteriores 2011: 78-79, 123-125, 173-175, 224-226, 277-278; González Vigil 2012: 236-240). Finally, Peru joined Chile, Colombia, and Mexico in creating the Alianza del Pacífico, a regional trade agreement formally established in June 2012 (La República, 10 February 2012).

With Ecuador, ongoing efforts to implement fully the 1998 Brasilia Accords continued with an emphasis on the borderlands. Various binational committees and commissions met on a regular basis, and after the November 2006 election of President Rafael Correa, who supported many of the policies advocated by Bolivia and Venezuela, Peru and Ecuador found common ground to advance their bilateral agenda. Symbolic of the strength of the bilateral relationship, President Correa was awarded the Gran Collar de la Orden El Sol del Perú during a June 2010 state visit to Peru. In May 2011, 
Peru and Ecuador fixed their maritime boundary, strengthening the Peruvian position in its maritime dispute with Chile (Trazegnies 2012; Ministerio de Relaciones Exteriores 2011: 48-49, 70-72, 111-13, 161-162, 180-181, 214-216, 270, 281).

Bilateral relations with Chile were strained at the end of the Toledo presidency, and Foreign Minister García Belaúnde hoped to improve them during President García's second term. Peru finalized a free commerce agreement with Chile in 2006, largely negotiated by the Toledo administration, and it also concluded a bilateral agreement covering domestic employees working in the country of the other. For some months, the disposition of ex-President Fujimori remained a contentious issue; however, the Chilean Supreme Court eventually authorized his extradition to Peru in September 2007. As for the maritime issue with Chile, President García supported the Toledo administration's decision to take the question to the International Court of Justice, appointing two-time foreign minister, Allan Wagner, as the agent for Peru at The Hague. Foreign Minister García Belaúnde later noted that Chile appeared amenable to compromise on smaller issues early in President García's second term in the hopes it would forestall a Peruvian decision to take the maritime issue to The Hague, but once that decision was taken, Chile became more intransigent (García Belaúnde 2014).

92 While progress was made in improving bilateral relations, the contentious maritime issue limited any widespread improvement, especially in the second half of the García administration (Brousset 2012: 329-330).

In mid-June 2006, President-elect García emphasized that his government would focus on wider South American union, adding Brazil was central to a broader relationship (Perí21, 
9 June 2006). In February 2008, President García was the first head of state to visit Brazil following President Lula's election to a second term, signing 12 new accords on technical cooperation, health, education, biotechnology, energymining, and Amazon security. In May 2008, President Lula made an official visit to Peru, concluding 10 new pacts, and in June 2010, Presidents García and Lula met in Manaus where they signed 12 new agreements, including accords on education, energy, finance, and health. Additional meetings at all levels of government occurred throughout the García presidency with the emphasis always on full implementation of the strategic alliance concluded by the Toledo government (St John 2016: 152-153; Zela 2012: 31-41).

With Colombia, the foreign policy of the García administration continued the focus of the previous government on borderland issues, including economic development in the frontier zone, increased commercial exchange, and heightened collaboration against narco-trafficking. With most of these topics related to questions of national security, the ministers of foreign affairs and defense of Peru and Colombia met on a regular basis in 2+2 meetings. In July 2008, Presidents García, Lula, and Uribe concluded a tripartite memorandum of understanding aimed at combating narco-trafficking in the Amazon region, and in March 2011, President García completed a state visit to Colombia (Ministerio de Relaciones Exteriores 2011: 69-70, 110-111, 160-161, 179180, 213-124, 269-70; Namihas 2012: 55-73).

In the course of the 2006 presidential campaign, García traded barbs with Hugo Chávez after the latter termed García "a swine, a gambler, and a thief" and characterized García and Toledo as "two alligators from the same swamp" (Mc- 
Clintock 2006, quote 104). Harshly critical of presidents Morales and Chávez during the presidential campaign, García reached out to them after his election in an attempt to calm the rhetoric. At the same time, he cast his administration as the regional antithesis of Chávez and Morales, arguing in Washington that a bilateral free trade pact was necessary to thwart the threat of "Andean Fundamentalism" in South America (Washington Post, 10 October 2006). In January 2007, while attending President Correa's inauguration, Presidents García and Chávez agreed to renew diplomatic ties, formally ending the rift that had begun during the 2006 presidential campaign (La República, 15 January 2007). However, after Peruvian police in March 2008 arrested nine people alleged to be militants bankrolled by Venezuela, the García administration was again accusing Chávez of meddling in the domestic affairs of Peru (Miami Herald, 22 March 2008). In the end, recurrent tensions with Venezuela proved a difficult balancing act for President García, hampering a sustained diplomatic reconciliation (Ministerio de Relaciones Exteriores 2011: 49, 73, 85-86, 272).

In contrast, Foreign Minister García Belaúnde made good progress in improving bilateral relations with Bolivia. An early source of Peruvian concern was a Bolivian agreement with Venezuela for the latter to fund military bases along

94 the Peruvian border. Bolivia's reluctance to accept the modifications to the CAN agreement necessary to implement Peru's free trade agreement with the United States and its refusal to negotiate a common CAN trade agreement with the European Union also frustrated Peruvian officials (Valdez 2012: 170-174). As late as June 2009, President Morales, in a critique of the capitalist system, described presidents Bush and García as the "peores presidentes del 
mundo" (La República, 23 June 2009), and in August 2009, Foreign Minister García Belaúnde described Evo Morales as "un enemigo declarado del Perú" (La República, 30 August 2009). In an effort to jump-start better relations, Foreign Minister García Belaúnde in late 2009 asked former Foreign Minister Manuel Rodríguez Cuadros to serve as the Peruvian ambassador to Bolivia, and upon assuming his new post, Ambassador Rodríguez immediately endorsed Bolivia's demand for an exit to the sea (El Comercio, 19 February 2010). In mid-October 2010, the first $2+2$ meeting of the foreign and defense ministers of Peru and Bolivia took place, and one day later, Presidents García and Morales met in Ilo to sign a complementary protocol to the 1992 "Boliviamar" agreement, providing Bolivia with a duty free zone and access to Peruvian port facilities. Additional meetings related to borderland development, the common management of Lake Titicaca, and other issues took place over the coming months as the García government worked to improve its relations with Bolivia (García-Corrochano 2012: 81-94; Ministerio de Relaciones Exteriores 2011: 45$46,68,107,155,210-211,230-231)$.

A seasoned diplomat, Ambassador José Antonio García Belaúnde was the foreign minister of Peru during the entire second presidency of Alan García, the first individual in Peruvian history to serve in that capacity throughout a full five-year presidential administration. Asked after he left office if the foreign policy of the García administration mirrored that of the Toledo government, Ambassador García Belaúnde gave a thoughtful response, "So, I would say that we had more clear ideas [than the Toledo administration] but not necessarily different," adding "we were less ideological, less biased, than Toledo.” Regarding President Fujimori and 
his extradition to Peru, he argued that the approach of the Toledo administration unduly soured relations with Japan and Chile. Therefore, one of the primary goals of the García administration was to normalize relations with Chile and Japan as well as with Bolivia and Venezuela, and in the end, it made considerable progress toward these goals. Ambassador García Belaúnde also noted the tendency of the Toledo administration to promise more than Peruvian diplomacy could deliver, suggesting Brazil, China, and Japan were three areas where the García administration moved diplomatic relationships forward (García Belaúnde 2014).

\section{More of the same, 2011-2016}

Like his predecessor, Ollanta Humala Tasso, a former army officer, reinvented himself in the course of the 2011 presidential campaign. In 2006, he was a fiery populist, drawing support from Hugo Chávez and Evo Morales, but by 2011, he had become a moderate, pro-business social democrat. During the election campaign, the Worker's Party of Brazil, the political party of President Dilma Vana Rousseff and former President Lula, threw its weight behind Humala with Brazilian political strategists and consultants helping to transform him from a far left politician into a more socially moderate one attractive to a broader base of support. In so doing, the Brazilian government presented the region with a new paradigm, an increasingly influential regional power willing to intervene in the domestic politics of a neighboring state when it felt its economic and political interests were at stake. Brazilian advice and support proved just enough to get Humala elected, winning a little more than 51 percent of the vote in a run-off election with Keiko Sofia Fujimo- 
ri Higuchi, daughter of former President Alberto Fujimori (Aramayo and Pereira 2011; St John 2016: 153-154).

The foreign policy of the Humala administration resembled the foreign policies of the Toledo and García administrations in many ways. As Foreign Minister Rafael Roncagliolo Orbegoso later emphasized: "La política exterior de los estados se basa en el interés nacional. Existen intereses permanentes y aquellos que responden a la coyuntura internacional" (Roncagliolo Orbegoso 2014). For example, Peru continued its participation in a number of regional and international organizations, including CAN, APEC, and the UN. It also continued ongoing efforts to protect and promote Peruvian culture, strengthen domestic institutions, and support Peruvians abroad (Ministerio de Relaciones Exteriores 2013: 2223, 31-32, 46-48, 60-62, 87-90; Ministerio de Relaciones Exteriores 2014: 20-21, 68-71, 101-126, 237-254). At the same time, Foreign Minister Roncagliolo argued that there was a qualitative difference to the foreign policy of the Humala administration, highlighting its emphasis on investment, regional infrastructure, and educational and cultural exchange (Roncagliolo Orbegoso 2014). During a February 2016 visit to Cuba, President Humala discussed with President Raúl Castro the need to protect the cultural heritage of both countries and to increase the number of Peruvians studying at Cuban medical schools (El Peruano, 19 February 2016). Similarly, when French President François Hollande visited Peru later in the month, President Humala welcomed a French commitment to increase the scholarships available to Peruvians to study in France (El Peruano, 24 February 2016).

President-elect Humala's first stop in a week-long tour of South America was Brazil where he met with President 
Rousseff, reaffirming their strategic relationship, and over the next 12 months, Humala and Rousseff met three more times (Novak and Namihas 2012: 202-207). In November 2013, President Rousseff marked the end of the first decade of the strategic alliance with a state visit to Peru. In a tweet before her arrival, she noted that more than 70 Brazilian companies were now operating in Peru where they had invested some $\$ 6$ billion, and she later noted that Peru ranked third in terms of Brazilian investments in South American states (Ministerio de Relaciones Exteriores 2014: 29-30). Thereafter, President Humala, described by The Economist magazine as a "pro-Brazilian social democrat" (Economist, 12 April 2014), maintained the momentum for increased integration with Brazil built up during the Toledo and García presidencies, building on old initiatives and introducing new ones (Roncagliolo 2014; St John 2016: 154-155).

Well before his election, President Humala had questioned the approach taken by the Toledo and García administrations to curb arms spending in Latin America, arguing Peru should equip its armed forces on the basis of a clear doctrine of national defense and not as a function of what Chile was doing (La República, 4 May 2009). While the Humala administration signed the Arms Trade Treaty in September 2013, it also supported a major upgrade of the Peruvian ar-

98 med forces. At the same time, President Humala threw his support behind the ongoing process at The Hague aimed at resolving the maritime dispute with Chile. Under the leadership of Ambassador Wagner, policy continuity on this issue led to a January 2014 ICJ decision awarding Peru well over half the disputed maritime space with Chile retaining the bulk of the coastal fishing grounds (International Court of Justice 2014). Foreign Minister Roncagliolo later charac- 
terized the foreign policy of the Humala administration as "free of ideological constraints that in the past motivated some unnecessary controversies with some of our neighbors," proudly describing the successful conclusion of the maritime dispute with Chile "as a process of delimitation of Peruvian territory that started with our national independence" (Roncagliolo Orbegoso 2014).

To mark the registration of the Peru-Ecuador maritime treaty at the United Nations, President-elect Humala visited Ecuador in late June 2011, declaring himself in favor of wider regional integration. Thereafter, representatives of Peru and Ecuador met regularly in a continuing attempt to implement fully all aspects of the Brasilia Accords, including wider borderland development, improved border security, accelerated demining, and reduced transnational crime (Ministerio de Relaciones Exteriores 2013: 26, 66-67; Ministerio de Relaciones Exteriores 2014; 25-26, 31-33, 136-137, 162164). Consistent with these goals, Peru and Ecuador in December 2015 agreed to create a 1.8 million acre biosphere reserve on their shared border (Telesurtv, 29 December 2015).

Bilateral relations with Colombia continued to focus on defense and security issues, together with borderland development. In mid-2013, the two neighbors adopted the Plan de Desarrollo de la Zona de Integración Fronteriza Perú-Colombia which focused on social, economic, and institutional projects and was designed to strengthen the presence of the state and to improve the quality of life in the frontier zone. In 2014, Peru and Colombia formed a binational cabinet, similar to the one created earlier by Peru and Ecuador, to add focus to the diverse issues faced in the borderland (Ministerio de Relaciones Exteriores 2013: 29-30, 56; Ministerio 
de Relaciones Exteriores 2014: 24, 31, 141, 159-160). At the second binational cabinet meeting in Medellín in October 2015, Presidents Humala and Santos focused on defense, development, and security issues in the frontier zone ( $\mathrm{El} \mathrm{Pe}$ ruano, 28 October 2015).

In September 2011, the Ministry of Foreign Affairs organized a symposium, "Diálogos sobre la Preservación y Promoción de la Democracia en las Américas" to commemorate the tenth anniversary of the adoption of the CDI. One year later, Foreign Minister Roncagliolo repeated calls made by the Toledo and García administrations in support of UN reforms, challenging the world body to better reflect the realities of the new millennium (Roncagliolo Orbegoso 2014). Relations with the Middle East continued to expand with a state visit by the Emir of Qatar in February 2013, the inauguration of a Peruvian embassy in Saudi Arabia in March 2013, and a state visit by President Recep Tayyip Erdogan of Turkey in February 2016. Stressing wider relations with the Arab world did not imply an anti-Israeli stance, Foreign Minister Roncagliolo later noted that President Humala in February 2014 visited Israel as well as Palestine and Qatar (Roncagliolo Orbegoso 2014). Peru also maintained its longtime support for UN peace-keeping missions (Sánchez 2014), and in December 2013, it launched its twenty-second

100 expedition to the Antarctic, continuing a policy dating back to the second Belaúnde administration (Belaúnde Terry, 1983; Sánchez and Tielemans 2015). In March 2016, Peru concluded an agreement with the European Union, enabling Peruvians to travel to the Schengen region for up to 90 days without a visa, a long-time foreign policy goal (El Comercio, 14 March 2016). 
During the 2011 presidential campaign, Humala had been highly critical of US policies; nevertheless, President Barack Obama reached out to him during his June 2011 informal visit to the White House. Thereafter, the Humala government softened its tone, expressing a desire to improve cooperation in areas like combating drug-related crime and terrorism. At the same time, it pursued increasingly friendly policies toward big business and multinational corporations (Renique 2013). During a June 2013 official visit to the White House, President Obama called Peru one of the "most reliable partners" in the hemisphere (Bloomberg, 11 June 2013), and President Humala described the Obama administration as "un socio con el cual se puede trabajar" (El Comercio, 11 June 2013). Reflecting the new mood, Caretas titled its coverage of Humala's visit to the White House "El Nuevo Consenso" (Caretas, 13 June 2013). In November 2013, Foreign Minister Eva Rivas Franchini, who replaced Roncagliolo in May 2013, characterized relations with Washington as being at "un nivel muy alto" (El Comercio, 22 November 2013). In another positive development, Lori Berenson concluded her 20-year prison sentence in December 2015 and returned to the United States, ending a controversy that had complicated bilateral relations for more than two decades (El Peruano, 16 December 2016).

In other areas, the Humala administration's foreign policy evidenced differences in approach or emphasis. In a quick visit to La Paz in late June 2011, President-elect Humala invited President Morales to consider bilateral integration in which the two countries would unite into a confederation reminiscent of the ill-fated Peru-Bolivia Confederation (18361839). Nothing concrete came of this proposal; however, in February 2013, Peru, Bolivia, and Brazil concluded a triparti- 
te agreement to fight organized crime and drug trafficking in their borderland areas (Ministerio de Relaciones Exteriores 2013: 28, 67-68). In September 2013, the Foreign Relations Committee of the Congress of Peru finally approved the "Boliviamar" agreement, concluded in 1992 and renewed and expanded in 2010. Before it came into effect, the agreement still required ratification by the full congress; nevertheless, the Morales government welcomed the committee's decision and talked of construction of a mega port near Ilo, together with a Bolivia-Brazil rail link (Ministerio de Relaciones Exteriores 2014: 29, 164). In July 2015, Peru and Bolivia concluded a "strategic alliance" consisting of more than 90 separate accords, and in January 2016, they initialed an agreement aimed at the environmental restoration of Lake Titicaca (La Razón, 12 January 2016).

Under President Humala, diplomatic and commercial relations with Russia reached a level not seen since the military ruled Peru during the docenio (1968-1980). When Russian Foreign Minister Sergey Lavrov visited Peru in April 2014 to celebrate the forty-fifth anniversary of the establishment of diplomatic relations, Peru had purchased or was exploring the purchase of Russian fighter planes, tanks, and helicopters as part of President Humala's upgrade of the Peruvian armed forces (Ministerio de Relaciones Exterio-

102 res 2014: 179). In so doing, the Humala administration reaffirmed a policy of diversified arms transfers dating back to the first Belaúnde administration. In the mid-1960s, the Peruvian government purchased 14 Dassault Mirage V fighter-bombers from France and six Canberra light bombers from the United Kingdom after the United States refused to sell Peru Northrop F-5A/B Freedom fighters (Cobas 1982: 152-159). In May 2014, Russian Prime Minister 
Dmitry Medvedev also visited Peru, signing a series of bilateral agreements on energy, hydrocarbons, scientific cooperation, and trade (Latin American Herald Tribune, 2 May 2014), and in November 2014, President Humala made a state visit to Russia, signing agreements on trade, climate protection, and tourism (El Peruano, 8 November 2014). Finally, on the sidelines of the UN Conference on Climate Change in Paris, Presidents Humala and Vladimir Putin in November 2015 concluded a "strategic partnership agreement," the scope and significance of which remained unclear (Sputnik News, 27 November 2015).

The Humala administration was aggressive in pursuing trade agreements around the world, but its actions here were more an affirmation of the policies of the Toledo and García administrations than a departure from them (Ministerio de Relaciones Exteriores 2013: 43-44, 73, 85-87; Ministerio de Relaciones Exteriores 2014: 38-43, 81-84, 144-154, 210 218). A free trade agreement with South Korea, concluded at the end of the García administration, took effect in August 2011, and in November 2011, the two states signed a new air services agreement. In March 2012, a free trade agreement with Japan negotiated during the García administration became effective, and in October 2013, Peru and Japan celebrated 140 years of diplomatic relations. In June 2012, Peru and Colombia concluded an ambitious and comprehensive trade agreement with the European Union which was approved by the Peruvian congress in December of that year (Stevens et al. 2012). The pact marked a milestone in Peruvian economic policy as it meant Peru now had similar agreements with every major economy in the world. At the time, the Humala administration was also engaged in free trade talks with several more states, including Indonesia, India, 
and Turkey. The Pacific Alliance member states also continued their efforts to integrate free markets in trade, energy, and infrastructure, agreeing in February 2014 to an additional protocol removing tariffs on 92 percent of goods and services (La República, 10 February 2014). In February 2016, Peru joined 11 other Pacific Rim states, including Chile and Mexico, in signing the controversial Trans-Pacific Partnership (TPP) (El Peruano, 4 February 2016).

When President Humala met with Chinese President $\mathrm{Hu}$ Jintao at the November 2011 APEC meeting in Honolulu, the two leaders pledged to work together to advance their strategic partnership (MercoPress, 30 November 2011), and at the end of the year, China surpassed the United States as Peru's main trading partner. During a February 2013 visit to China, Foreign Minister Roncagliolo announced that Peru and China had agreed to quadruple the number of scholarships available to Peruvian students to study in China, especially in science and technology. By this time, bilateral trade had more than doubled since the Peru-China free trade agreement took effect in 2010. In April 2013, President Humala also visited China where he met with President Xi Jinping and promoted Peruvian exports and Chinese investment (Ministerio de Relaciones Exteriores 2013: 36, 82). Motivated in part by a desire to reduce shipping costs and

104 avoid the Panama Canal, China continued to express interest in constructing an Amazonian railway linking the Atlantic coast of Brazil to the Pacific coast of Peru, a project recently elected President Pedro Pablo Kuczynski suggested might be too expensive and environmentally harmful to build (Asia Times, 13 September 2016). Finally, a Chinese naval hospital ship paid a seven-day service call at Lima's port of Callao in December 2015, its first-ever stop at a South American port 
and a fresh sign of China's growing influence in the region (Associated Press, 22 December 2015).

As with many states in and out of the region, stable governments, secure societies, and strong economies have often been challenges for Peru. Presidents Toledo, García, and Humala respected the constitutional prohibition on consecutive presidential terms, and for the first time in decades, Peru in 2006, 2011, and 2016 had a change of government without a serious political or economic crisis. At the same time, the macroeconomic policies pursued after 1990 helped the Peruvian economy in 2000-2014 to grow an average of 5.3 percent annually or 79.6 percent over the period, the highest collective growth rate in South America and second only to Panama for all of Latin America. The Peruvian economy also compared well with those of its neighbors in terms of constant, sustained economic growth, and the long-term outlook for the Peruvian economy remained favorable (Notimérica 2016; Focus Economics 2016).

\section{Concluding observations}

Following almost three decades of experimentation, Peruvian foreign policy in the new millennium returned to more traditional interests and concerns. The Fujimori administration set the stage for this adjustment in the final decade of the last century. Once his orthodox economic policies had begun to bear fruit, President Fujimori introduced several creative initiatives, shifting the direction, content, and tone of Peruvian foreign policy. Central elements of this transition included increased support for free trade and market reform, a renewed commitment to regional and internatio- 
nal cooperation, a recognition of the changing role of the United States in world politics, and a resultant commitment to wider, deeper relations with Asia and Europe. Thereafter, successive presidential administrations, from Toledo to $\mathrm{Hu}-$ mala, refined and build upon these initiatives in pursuit of a foreign policy characterized more by continuity than change.

In support of the traditional goals of sovereignty and territorial integrity, President Fujimori and his successors successfully resolved a territorial dispute with Ecuador outstanding from the independence era, terrestrial and maritime disputes with Chile dating back to the nineteenth century, and the more recent maritime issue with Ecuador. In so doing, the Peruvian government successfully resolved the last of a number of territorial and related issues that had bedeviled Peruvian foreign policy since independence. Consequently, Peruvian diplomacy with its South American neighbors, Bolivia, Brazil, Chile, Colombia, and Ecuador, was finally able to shift from the resolution of long-time territorial or maritime issues to more fruitful cooperative efforts in their respective borderlands focused on enhancing border security, promoting economic development, and reducing transnational crime.

Reflecting a long-time commitment to regionalism and continental solidarity, the Peruvian government was an active

106 participant in the Andean Community of Nations, through it joined the Common Market of the South, and more recently, the four-member Pacific Alliance. Even as Peru remained a member of the Organization of American States, successive Peruvian governments both widened their horizon of regional concerns and strengthened their commitment to continental solidarity, actively participating in new organizations like the Rio Group and the South American Community 
of Nations, later renamed the Union of South American Nations. While most of these organizations had economic concerns as a core agenda, successive Peruvian governments also used them to advance political agendas, notably support for democracy and human rights, reduced arms expenditure, and reform at the United Nations.

In addition to the United Nations, the Peruvian government was also active in an increasing number of relatively new international organizations and institutions. Its participation in groupings like the Asia-Pacific Economic Cooperation forum, Summit of South American-Arab Countries, and Organization of Ibero-American States was generally more symbolic than tangible in benefit. At the same time, these bodies provided opportunities for senior Peruvian officials to meet with their counterparts from other countries, thus contributing indirectly or directly to broader commercial and diplomatic ties with Asian states and the Arab world.

In common with most of the nations of the world, size has long impacted on the foreign policy capabilities of Peru. Increasingly active in a plethora of international organizations, the Peruvian government in the new millennium appeared at times to be threatened with what might be termed summit overload, an affliction common in small to mid-sized powers. Most of these states belong to a growing number of economic and political groupings, many of which hold annual summits that heads of state or senior officials are expected to attend, putting a severe strain on the limited capacity of states of a certain size to staff.

Economic independence remained a central goal of Peruvian foreign policy in the new millennium. In line with ge- 
nerally orthodox economic policies emphasizing free trade and market reforms, the Peruvian economy continued its reliance on export-led growth; consequently, trade policy and foreign policy remained inextricably intertwined. With the US footprint in Latin America lighter, less distinct, and less forceful than it had been for many decades, Peruvian governments increasingly looked to Asia and Europe as well as to neighboring states like Brazil to diversify exports, develop human capital, and modernize physical infrastructure. The strategic alliance with Brazil proved advantageous to Peru from a number of different economic and security perspectives; however, its diplomatic and political benefits were less clear. Given the asymmetrical nature of the bilateral relationship, Brazil will continue to have a significant impact on the domestic and foreign policies of Peru, but Peru will have a more limited ability to impact on policy-makers or policy in Brazil. Concomitant with its growing presence in Latin America, China is also positioned to play an increasingly important economic role in Peru and neighboring states. Moreover, the reorientation of trade and investment policies and partners that has taken place in recent years can be expected to continue in the future as exemplified by the recent Peruvian commitment to the Trans-Pacific Partnership.

Issues of sovereignty, territorial integrity, regionalism, con108 tinental solidarity, and economic independence have been central to the foreign policy of Peru since its foundation in 1821. In the new millennium, successive Peruvian governments have addressed these issue areas in a foreign policy grounded in pragmatism and notable for rational, consistent, and mostly achievable initiatives that largely complemented and supported each other. At the same time, the restoration of the professionalism and integrity of the Peruvian diplo- 
matic corps, following the scandal of the 1990s, ensured that successive governments had the diplomatic skills and tools required to pursue new initiatives in an ever-changing world. Faced with new diplomatic, economic, and political realities, Peruvian foreign policy remained grounded in tradition even as it shifted to take advantage of new opportunities in an increasingly multicultural and multipolar world.

Recibido: 06 de junio del 2016

Aprobado: 11 de agosto del 2016

\section{Bibliography}

ÁLVAREZ-RODRICH, Augusto

2008 Journalist and editor (Perú21), interview with author, Lima, Peru, 12 March.

ARAMAYO, Carlos y Carlos PEREIRA

2011 Brazil's Influence in Peru's 2011 Presidential Election, Brookings Institution, 14 June. http:/ / www.brookings.edu.

ARRÓSPIDE DEL BUSTO, José Antonio

2008 Executive director of the Perú-Ecuador binational development plan (2006-2010), interview with author, Lima, Peru, 13 March.

AVERY, William P.

1983 "The Politics of Crisis and Cooperation in the Andean Group". Journal of Developing Areas, 17, 2 (January): 156-165.

BÁKULA, Juan Miguel

2002 Perú: entre la realidad y la utopía, 180 años de política exterior. 2 vols. Lima: Fondo de Cultura Económica, Fundación Academia Diplomática del Perú. 
BELAÚNDE TERRY, Fernando

1983 President of Peru (1963-1968, 1980-1986), interview with author, Lima, Peru, 11 July.

BERENSON, Mark L.

2005 "Peru vs. Lori Berenson: The Case Continues". NACLA Report on the Americas, 38, 5: 4-5. https://doi.org/10.1080/10714839.2005.11722373

BOLOÑA, Carlos

1996 "The Viability of Alberto Fujimori's Economic Strategy". In GONZALES DE OLARTE, Efraín (editor). The Peruvian Economy and Structural Adjustment: Past, Present, and Future. Miami, FL: North-South Center Press, pp. 183-264.

BROUSSET, Jorge

2012 "Política exterior y asuntos marítimos". In NOVAK, Fabián (coordinador). Veinte años de política exterior peruana (1991-2011). Lima: Fondo Editorial de la Pontificia Universidad Católica del Perú, pp. 321-344.

COBAS, Efraín

1982

Fuerza armada, misiones militares y dependencia en el Perú, Lima: Editorial Horizonte.

ERGUETA ÁVILA, Edgar

2000 "ILO: diagnóstico y proyecciones". In ZELADA CASTEDO, Alberto (coordinador). Bolivia: temas de la agenda internacional. La Paz: Ministerio de Relaciones Exteriores y Culto, pp. 93-120.

FFRENCH-DAVIS, Ricardo

1978

"El Pacto Andino: un modelo original de integración". In TIRONI, Ernesto (coordinador). Pacto Andino: carácter y perspectivas. Lima: Instituto de Estudios Peruanos, pp. 25-70. 
FOCUS ECONOMICS

2016 "Peru Economic Outlook". 16 February. http:// www.focus-

economics.com/countries/peru.

GARCÍA, Jaime

2012 "Relaciones económicos y comerciales entre el Perú y los países árabes". In NOVAK, Fabián (coordinador). Veinte años de politica exteriorperuana (1991-2011), Lima: Fondo Editorial de la Pontificia Universidad Católica del Perú, pp. 243-269.

GARCÍA BELAÚNDE, José Antonio

2014 Foreign minister of Peru July 2006-July 2011, interview with author. Lima, Peru, 14 January.

GARCÍA-CORROCHANO, Luis

2012 "La política exterior del Perú respecto de Bolivia y Chile (1992-2012). In NOVAK, Fabián (coordinador. Veinte años de política exterior peruana (1991-2011). Lima: Fondo Editorial de la Pontificia Universidad Católica del Perú, pp. 75-94.

GARCÍA-SAYÁN, Diego

2008 Foreign minister of Peru July 2001-July 2002, interview with author. Lima, Peru, 11 March.

2002 Una nueva política exterior peruana: Democrática, moderna, independiente y al servicio de la gente. Lima: Comisión Andina de Juristas y Academia Diplomática del Perú.

GARDINER, C. Harvey

1975 The Japanese and Peru: 1873-1973. Albuquerque, NM:

University of New Mexico Press.

GONZÁLEZ VIGIL, Fernando

2012 "Relaciones de comercio e inversión del Perú con el Asia-Pacífico". In NOVAK, Fabián (coordinador). Veinte años de política exteriorperuana (1991-2011). 
Lima: Fondo Editorial de la Pontificia Universidad Católica del Perú, pp. 209-241.

IGUÍÑEZ, Javier

1998 "The Economic Strategy of the Fujimori Government". In CRABTREE, John and Jim THOMAS (editors). Fujimori's Peru: The Political Economy. London: Institute of Latin American Studies, University of London, pp. 24-40.

INTERNATIONAL COURT OF JUSTICE

2014 Maritime Dispute (Peru v. Chile): Judgment, General List No. 137. The Hague, 27 January.

LUNA, Ricardo

1999 Peruvian ambassador to the United States 19921999, interview with author. Lima, Peru, 1 September.

MAÚRTUA DE ROMAÑA, Oscar

2006 Foreign minister of Peru August 2005-July 2006, interview with author. Lima, Peru, 18 April.

MCCLINTOCK, Cynthia

2006 "An Unlikely Comeback in Peru". Journal of Democracy, 17, 4: 95-109.

https://doi.org/10.1353/jod.2006.0066

MCCLINTOCK, Cynthia y Fabián VALLAS

2010 "The United States and Peru in the 2000s". In DOMÍNGUEZ, Jorge I. and Rafael FERNÁNDEZ DE CASTRO (editors).Contemporary U.S.-Latin American Relations: Cooperation or Conflict in the $21^{15 t}$ Century? London: Routledge, 2010, pp. 197-217.

2003

The United States and Peru: Cooperation at a Cost. London: Routledge. 


\section{MINISTERIO DE RELACIONES EXTERIORES}

2014 Memoria institucional de 15 de mayo de 2013 al 24 de junio de 2014. Lima: Ministerio de Relaciones Exteriores. http://transparencia.rree.gob.pe/index.php/2planeamiento-y-organizacion/2-5-memoriainstitucional/8019-3-memoria-institucional- d e eda-rivas-franchini-2013-2014/file

2013 Memoria institucional del 28 de julio de 2011 al 15 de mayo del 2013, Lima: Ministerio de Relaciones Exteriores.

2011 Memoria del Ministerio de Relaciones Exteriores, julio 2006 julio 2011. Lima: Ministerio de Relaciones Exteriores. http://rree.gob.pe/politicaexterior/Documents / MEMORIA-del-MRE-Jul-2006-Jul2011.pdf.

2006a Memoria institucional, agosto 2005-julio 2006. Lima: Ministerio de Relaciones Exteriores.

2006b Política exterior peruana, julio 2001-marzo 2006. Lima: Ministerio de Relaciones Exteriores.

2006c Un lider sin fronteras: Diplomacia presidencial, 2001-2006. Lima: Oficina General de Comunicaciones.

MORIMOTO, Amelia

1999 Los japoneses y sus descendientes en el Perú. Lima: Fondo Editorial del Congreso del Perú.

NAMIHAS, Sandra

2012

"La construcción de una asociación estratégica y un desarrollo fronterizo entre el Perú y Colombia". In NOVAK, Fabián (coordinador). Veinte años de politica exterior peruana (1991-2011). Lima: Fondo Editorial de la Pontificia Universidad Católica del Perú, pp. 53-74.

NEGRO, Dante

2012 "Las relaciones entre el Perú y la OEA (1991-2011)". In NOVAK, Fabián (coordinador). Veinte años de poli- 
tica exterior peruana (1991-2011). Lima: Fondo Editorial de la Pontificia Universidad Católica del Perú, pp. 273-304.

NOTIMÉRICA

2016 “QQué economía iberoamericana ha crecido más este milenio?”. 16 February.

http://www.notimerica.com/economia/noticiaeconomia-iberoamericana-crecido-mas-milenio-20160216084232.html);

NOVAK, Fabián

2012 "Las relaciones entre el Perú y Europa: Los casos de Alemania, España y Francia". In NOVAK, Fabián (coordinador). Veinte años de política exterior peruana (1991-2011). Lima: Fondo Editorial de la Pontificia Universidad Católica del Perú, pp. 175-205.

2000 Las conversaciones entre Perú y Chile para la ejecución del tratado de 1929. Lima: Fondo Editorial de la Pontificia Universidad Católica del Perú.

NOVAK, Fabián y Sandra NAMIHAS

2012 Las relaciones entre el Perú y Brasil (1826-2012). Lima: Pontificia Universidad Católica del Perú, Konrad Adenauer Stiftung.

PALMER, David Scott

1998 "Relaciones entre Estados Unidos y el Perú durante el decenio de 1990: dinámicas, antecedentes y proyecciones". Politica Internacional 53 (julio/setiembre): 23-45.

PANIAGUA, Valentín

2001 President of Peru 2000-2001, interview with author, Lima, Peru, 16 March.

PÉREZ DE CUÉLLAR, Javier

2012 Memorias: Recuerdos personales y políticos. Lima: Aguilar. 
PHILIP, George y Francisco PANIZZA

2011 The Triumph of Politics: The Return of the Left in Venezuela, Bolivia and Ecuador. Cambridge: Polity.

PUENTE RADBILL, José de la

2003 Foreign minister of Peru July 1976-January 1979, interview with author, Lima, Peru, 9 May.

QUIROZ, Alfonso W.

2008

Corrupt Circles: A History of Unbound Graft in Peru. Washington, D.C.: Woodrow Wilson Center Press and Baltimore, MD: Johns Hopkins University Press.

RAMACCIOTTI, Beatriz y María MÉNDEZ

2012 "Las relaciones entre Perú y Estados Unidos: Dos décadas de asociación convergente". In NOVAK, Fabián (coordinador). Veinte años de política exterior peruana (1991-2011). Lima: Fondo Editorial de la Pontificia Universidad Católica del Perú, pp. 95-140.

RENIQUE, Gerardo

2013 "Peru: Humala Submits to the United States and the Mining Industry". NACLA Report on the Americas, 46, 3: 12-17.

RODRÍGUEZ CUADROS, José Manuel

2008 Foreign minister of Peru December 2003-August

2005, interview with author, Lima, Peru, 14 March.

RONCAGLIOLO ORBEGOSO, Rafael

2014 Foreign minister of Peru July 2011-May 2013, interview with author via e-mail, Lima, Peru, 20 October.

ROSPIGLIOSI, Fernando

$2000 \quad$ Montesinos y las fuerzas armadas: Cómo controló durante una década las instituciones militares. Lima: Instituto de Estudios Peruanos. 
ST JOHN, Ronald Bruce

2016 "The Peruvian Response to the Rise of Brazil: Developing a Strategic Relationship". In GARDINI, Gian Luca and Maria Herminia TAVARES DE ALMEIDA (editors). Foreign Policy Responses to the Rise of Brazil: Balancing Power in Emerging States. London: Palgrave Macmillan, pp. 145-159.

https://doi.org/10.1007/978-1-137-51669-5_10

2010 Toledo's Peru: Vision and Reality. Gainesville: University Press of Florida.

https://doi.org/10.5744/florida/9780813035215.001.0001

2006a "Evo Morales No Che Guevara". Foreign Policy in Focus, 9 January. http:/ /www.fpif.org.

2006b "Politics of Peru in Flux". Foreign Policy in Focus, 29 June.

http://www.fpif.org.

2005 "Bolivia Steps Back from the Abyss". Foreign Policy in Focus, 15 July. http://www.fpif.org.

2003 "New Solutions to Old Problems in Latin America". Foreign Policy in Focus, 22 May.

http:/ /www.fpif.org.

2000 "Chile, Peru and the Treaty of 1929: The Final Settlement". IBRU Boundary and Security Bulletin, 8 (1): 91-100.

1999a Ecuador-Peru Boundary Dispute: The Road to Settlement, International Boundaries Research Unit, University of Durham, Boundary and Territory Briefing, 3 (1).

1999b La politica exterior del Perú. Lima: Asociación de Funcionarios del Servicio Diplomático del Perú. 

don and Jean-Philippe THÉRIEN (editors). Foreign Policy \& Regionalism in the Americas, Boulder, CO: Lynne Rienner, 121-36.

1994

The Bolivia-Chile-Peru Dispute in the Atacama Desert. International Boundaries Research Unit, University of Durham, Boundary and Territory Briefing, 1 (6).

SÁNCHEZ, Wilder Alejandro

2014 "Misiones singularmente complicadas: El rol del Perú en las operaciones de paz de las Naciones Unidas". Perspectivas, 2: 7-19.

https://doi.org/10.1080/2154896x.2015.1030164

SÁNCHEZ, Wilder Alejandro y Otto Raul TIELEMANS Jr.

2015 "Reinvigorating Peru's role in Antarctic geopolitics". Polar Journal, 5, 1: 101-12.

SÁNCHEZ DE LOZADA, Gonzalo

2003 President of Bolivia (1993-1997, 2002-2003), interview with author, Bloomington, IL, 9 September.

SEOANE FLORES, Alfredo V.

2000 "Estado actual y proyecciones de la Comunidad Andina de Naciones". In ZELADA CASTEDO, Alberto (coordinador). Bolivia: Temas de la agenda internacional. La Paz: Ministerio de Relaciones y Culto, pp. 291-312.

STEVENS, Christopher y otros

2012 "European Union: Trade Agreement with Colombia and Peru". Directorate-General for External Policies, Policy Department.

https:/ /www.odi.org/publications/6415-europeanunion-trade-agreement-colombia-peru. 
TAPIA SAMANIEGO, Hildebrando

2011 Peruanos en el exterior. Lima: Fondo Editorial del Congreso del Perú.

TOLEDO, Alejandro

2008 President of Peru, 2001-2006, interview with author, Palo Alto, CA, 12 September.

2006 Mensaje del presidente constitucional del Perú, doctor Alejandro Toledo Manrique, ante el Congreso Nacional, el 28 de julio de 2006.

http://www4.congreso.gob.pe/museo/mensajes/ Mensaje-2006-1.asp

2006 President of Peru 2001-2006, interview with author, Lima, Peru, 19 April.

2003 President of Peru 2001-2006, interview with author, Lima, Peru, 9 May.

2001 Mensaje del presidente constitucional del Perú, doctor Alejandro Toledo Manrique, ante el Congreso Nacional, el 28 de julio de 2001.

http://www4.congreso.gob.pe/museo/mensajes/ Mensaje-2001-2.asp

TRAZEGNIES, Fernando de

2012 "Las relaciones entre Perú y Ecuador: caminando juntos". In NOVAK, Fabían (coordinador). Veinte años de política exterior peruana (1991-2011). Lima: Fondo Editorial de la Pontificia Universidad Católica del Perú, pp. 43-51.

1999

Foreign minister of Peru (October 1998-November 2000), interview with author, Lima, Peru, 2 September. 
TUDELA, Francisco

1999 Foreign minister of Peru July 1995-July 1997, interview with author, Lima, Peru, 31 August.

VALDEZ, Jorge

2012 "Las relaciones del Perú con la Europa comunitaria". In NOVAK, Fabían (coordinador). Veinte años de política exterior peruana (1991-2011), Lima: Fondo Editorial de la Pontificia Universidad Católica del Perú, pp. 161-74.

WAGNER, Allan

2003 Foreign minister of Peru, July 1985-May 1988, July 2002-December 2003, interview with author, Lima, Peru, 9 May.

ZELA, Hugo de

2012 "Las relaciones entre Perú y Brasil: La profundización de la alianza estratégica". In NOVAK, Fabían (coordinador). Veinte años de política exterior peruana (1991-2011). Lima: Fondo Editorial de la Pontificia Universidad Católica del Perú, pp. 15-41. 